\title{
School Physical Education: Welfare, Motivation and Positive Psychology
}

\author{
Marcio Alessandro Cossio Baez¹, Claus Dieter Stobäus², Juan José Mouriño Mosquera ${ }^{3}$ \\ ${ }^{1}$ Graduate Programs in Physical Education, Universidade Federal do Pampa-UNIPAMPA (or Pampa Federal University), Uruguaiana, \\ Brazil \\ ${ }^{2}$ Postgraduate Programs in Education and in Biomedical Gerontology, Pontifical Chatolic University of Rio Grande do Sul, Porto Alegre, \\ Brazil \\ ${ }^{3}$ Postgraduate Program in Education, Pontifical Chatolic University of Rio Grande do Sul, Porto Alegre, Brazil \\ Email: stobaus@pucrs.br
}

How to cite this paper: Baez, M. A. C., Stobäus, C. D., \& Mosquera, J. J. M. (2016) School Physical Education: Welfare, Motivation and Positive Psychology. Creative Education, 7, 2476-2489. http://dx.doi.org/10.4236/ce.2016.716235

Received: August 9, 2016

Accepted: October 212016

Published: October 24, 2016

Copyright $\odot 2016$ by authors and Scientific Research Publishing Inc. This work is licensed under the Creative Commons Attribution International License (CC BY 4.0).

http://creativecommons.org/licenses/by/4.0/ (c) (i) Open Access

\begin{abstract}
The study is a reflection about a part of the theoretical foundation of the doctoral thesis: "The process of building the welfare and quality of life during training in physical education and their future prospects in the direction of Positive Psychology" and the discussions between the authors can be characterized as a theoretical revision. Despite its importance for learning, motivation rarely receives due attention of teachers and researchers. Now with the flourishing of the Positive Psychology in the area, a new study bias that can discuss the importance of knowing better and giving intentional application of motivational concepts begins. Under the influence of positive aspects, it can favor the development of teachers and student positive relationships at the school during their educational process. In this perspective, the teachers must recognize not only planning topics such as methodology, content, evaluation and objectives, but also considering the emotional and motivational dimensions of its operations; they must search through strategies to establish links that contribute to personal flourishing. Therefore, it is evident that it needs to analyze the scenarios of which students come, and what they want to empower on themselves. At the same time, not forgetting the specific topics above, teachers will be able to improve enjoyable environments for their students. As well, as partakers help children, youth and also many adults who all seek sense of wellbeing in educational settings, through the construction of a healthy personal and community project, which is aimed at their maximum possible human potential development.
\end{abstract}

\section{Keywords}

Positive Psychology, Welfare, Motivation, School Physical Education 


\section{Introduction}

When a person starts a physical activity program or a sport, because a health necessity or by personal conviction, the greatest difficulty you may encounter is the adherence to this long-term activity, and it is widely recognized that the beneficial effects of any continued activity to improve health depend exactly on its adoption for a long active lifestyle period.

Ii is already widely known that the beneficial effects of any ongoing activity to preserve and improve health depend exactly on its adoption for a long period, known as a (pro)active lifestyle.

The positive and continued motivation also has a great effect on people, especially when it relates to physical activity in general.

In 1998, Martin Seligman (2004), as the presidency of the American Psychological Association (APA), launched the Positive Psychology in order to redirect the focus of interest of psychology, failing to investigate the dysfunctional affective states, to engage in positive emotions, virtues and personal strengths, making studies on the more positive subjective experience, positive individual and institutional positive characteristics.

The propose of Seligman was intended that Psychology failed to deal only as a healing profession turned to the use of positive qualities, devoting himself to investigating positive affective states, happiness, resilience, optimism, gratitude, contentment, quality of life, and satisfaction with life, among others.

Within this our work, searches support the relationship of the study between the motivational facts to help and elements coming from the Positive Psychology, as Seligman (2011) has contributed, the "flourishing of the people", in the case of the school in their activities in/to classes Physical Education.

This paper is based on our (Baez, Stobäus, \& Mosquera, 2013) presentation at the Health Psychology Congress at Faro-PT, and recently discussed at the International Conference on Positive Psychology and Cognitive Behavioral Therapy (Baez, Stobäus, \& Mosquera, 2016).

\section{Theoretical Review}

The main objective, with the use of a theoretical review, is to give subsidies for teaches and learners on the knowledge about motivation, welfare and Positive Psychology, especially in the direction of Physical Education and Education. It examines the relationships between motivation, positive psychology, and physical education teachers' practices in physical education, as it was explored in the Baez's Thesis (Baez, 2015).

\section{Positive Psychology and Education}

The named Positive Psychology movement emerged in the United States in 1998 from the initiative of Martin Seligman, in collaboration with other researchers, started to develop quantitative research to promote a change in the current focus of psychology or current approaches (Graziano, 2005). 
This perspective proposes to focus modification Psychology of compensation of less positive aspects of life for the construction of more positive qualities (Seligman, 2004). He said that the Positive Psychology is based on three main pillars, namely: the study of positive emotion; the study of traits or positive qualities, especially strengths and virtues, including skills such as intelligence and athleticism; and finally, the study of so-called positive institutions, such as democracy, family and freedom-that support the virtues which, in turn, provide support for positive emotions.

He points out that it is the study of feelings, emotions, at institutions and positive behaviors that have the ultimate goal of human happiness.

So Positive Psychology aims to look into the positive experiences (such as positive emotions, happiness, hope and joy), positive individual characteristics (such as character strengths and virtues), and positive institutions (such as organizations based on success and human potential are workplaces, schools, families, hospitals, communities or societies), proposed Seligman (2004).

According to this new vision, the knowledge of the strengths and virtues could provide the flowering (flourishing) of the potential of people, communities and institutions.

According Paludo \& Koller (2007), flowering has been a term widely used in Positive Psychology, it is a condition that allows development full, healthy and positive psychological, biological and social aspects of human beings

\section{Motivation in Education}

The motivation is understood, according Huertas (2001) as a psychological process, is provided by means of mood and emotional components. However, people have different types of motivation for a particular subject, because they create goals for their lives, their careers or even when traveling, and it is these goals that motivate them to continue their goals and purposes. For him, the motivation is the psychic energy of a man.

According to the studies of Fita (1999, p. 77), "motivation is a set of variables that enable the conduct and guide it in a certain way in order to achieve a goal". Thus, the motivation is to certain actions that cause people to reach their goals, since (p. 81):

The causes to which students attribute their successes or failures can be classified according to different criteria: internal or external causes, according to the causes they are within the subject or otherwise, stable or unstable, according to respond to something permanent or changeable, and finally, controllable or uncontrollable, as is possible or not to intervene therein.

Something to be considered is the use of these terms, which were firstly mentioned by Maslow (1991), in the 40 and 50-decade last century, when he said that there are two basic types of motivation: the extrinsic, more related to external forces that can intervenient on the subject, as parents, school, teacher, media, money, recompenses. In the other way, there are the intrinsic motivation related to the internal forces, as beliefs, attitudes, ideas one have, directing it to a goal. 
Huertas (2001) points out that there are two types of motivation: intrinsic motivation and extrinsic motivation. Intrinsic motivation is related to the interest of the activity itself, which has an end in itself and not as a means to other goals. It can be regarded as an independent motivational system of others, which supports a particular type of anticipation goals and a set of beliefs and attitudes.

For him, when an action is intrinsically regulated, it is based on three main features: self-determination; competence and satisfaction in doing something himself and family.

According Fita (1999, p. 78), "the very subject of study in the individual awakens an attraction that drives him to deepen it and to overcome the obstacles that may go performing throughout the learning process".

Extrinsic motivation is related to routines that we learn throughout our lives.

According Huertas (2001), when the purpose of the action, the goal and purpose relate to an external contingency, with a promise of a tangible benefit and outdoor, talking about extrinsic motivation. You could say that the extrinsic motivation is one that comes out, and is associated with matter, remuneration, have.

In teaching and learning processes, motivation must be present in all its moments. In this regard, Fita (1999) explains that we often say that motivation for the student to have in class, it is important to have a good teacher. Also hears it said that a good teacher is one who knows how to motivate his student.

According to this position, Huertas (2001) points out that all motivation must be related to goals and objectives, so a good teacher has (good and consistent) educational goals, which will make the student motivated to learn.

The author also states that the targets MUST BE triggering TO A motivated conduct, AND form part of the essential core to consider an action as motivated or not.

Therefore, without desire and goals, there is no motivation. However, to be a learner, it is also necessary to have (some) level of motivation.

The role of the teacher, according Huertas (2001, p. 256), is not to influence the student about their skills, knowledge and attitudes, but to facilitate the construction on their part of the training process. Faced with this idea, the teacher will influence the student in developing the motivation of learning. For this author, the more conscious is the teacher regarding the motivation, the better the learning of their students, and "motivation at school depends more on the type of goals that regularly arises a student's type of assignments to do".

For Deci \& Ryan (2000), intrinsic motivation corresponds to a self-determined behavior, and the interest in an activity is guided by free choice, is spontaneous and the person has curiosity, is not linked to external contingencies or rewards.

In this term, when tasks end themselves, intrinsically motivated behavior (by students, teachers and parents) is associated with feelings of satisfaction, fulfillment and pleasure (Deci \& Ryan, 1985).

In the extrinsic motivation, the activities or tasks are subject to the achievement of a goal/outcome, and in this situation the realization of actions are closely related to rewards, reviews, punishments, praise, among others. The determinations of the behaviors are much more associated with control, by external elements, which made the 
person acts under pressure, with no free will/autonomy. In these (external) controlled behaviors, the person perceives the activities/tasks as instrumental for achieving certain goals.

Several theorists have different perceptions about the motivation. Machado \& Gouvêa (1997), for example, conceptualized as an internal motive factor unobservable and that directs the behavior.

Moreover, the behavior of a subject 'maybe divided' into two aspects: the impulse of internal process, which causes the individual action, directing to a motivation and behavior that ends or decreases, when the objective is achieved. So he/she must achieve another new goal (or be exposed by one, in the school by a teacher, i.e.).

The same authors report that the aspirations of the students determine the motivation for a particular sport, that is, it can be basketball or handball. We can also say that children between 2 and 6 - 7 years old have rapidly changes in their motivations, specially by these media exposure, like the recent Olympic and Para-Olympic games of 2016.

Similarly to the biological requirements are inherent to the individual, so is intrinsic motivation. According Forties et al. (1995 cited by Gouvêa, 1997), it is characterized as an exercise for yourself, conducted just for the satisfaction of practice and perform, with no other interest. It is inherent to the object and the material to be learned, not depending on external elements.

In another perspective (dos Santos, Antunes, Mosquera, \& Stobäus, 2016), we can remember the ideas of Deci \& Ryan (2000) about intrinsic motivation, that:

'[...] corresponds to a typically self-determined behavior, in which the interest in an activity is guided by free choice, by spontaneity and curiosity. The efforts dedicated to the realization of an activity are not linked to external contingencies and rewards, but with the inherent characteristics to activity".

Or, as we said (dos Santos, Antunes, Mosquera, \& Stobäus, 2016):

"However, the motivational process has relations with the origin of the reasons that precede a goal and the consciousness we have of them. In every situation in which an individual think and then act, it is an implicit target, which can refer to many different individual intentions, for example, the improvement in Education, the achievement of something as desire, among others. The goals in this sense can be characterized as affective, cognitive, personal relationships, organizational subjectivity, or even related to the actual task to which one is intended".

Therefore, we can find some relations between the goals that the teacher wants to implement in her/his classes, and the performances of their students, as requirement for their own learning processes, can be perceived as more externally or internally directed.

\section{Physical Education Practices}

One of the main factors that interfere with a person's behavior is undoubtedly the mo- 
tivation, influencing, very properly in all kinds of behaviors, allowing greater involvement or mere participation in activities that are related to: learning, performance and Heads up.

With regard to physical education, the situation looks similar, it can be said that depends heavily on students' aspirations for a particular motivational element has a positive function, i.e., a student may feel more motivated to play basketball, and other one may feel the same within respect to volleyball.

It is also a note to the teacher, that, in whatever its participation (as a coach, teacher, trainer, manager, family, or other), their personality, their appearance, naturally, dynamism, enthusiasm for work, good humor, cordiality and disposal are some of the important motivational factors observed by those around them.

Machado (1997) mentions that there are many reasons responsible for the proper development and performance in the acquisition and maintenance skills. There are several types of activities and not all involve muscle movement (listen to a lecture is a different activity to participate in a debate, play football or dramatize a text).

Generally, the activities that require more participation, more moves, focus more reasons participants, arousing greater interest and challenge, which in itself may already be stimulating and motivating.

A well-planned and administered psychological preparation in routine activities able to work the motivational level, acquiring greater confidence, emotional balance and the individual armed with these qualities can transpose the other performance barriers, such as problems: opponents, environment, arbitration, integration with the group, personality and fitness.

For Magill (1984), motivation is important to the understanding of learning and performance of motor skills, it has an important role in the initiation, maintenance and intensity behavior.

Without the presence of motivation, students in physical education classes do not carry out the activities or else bad will do what is offered to it.

In a revision of these themes (Baez, Sampaio, Stobäus, \& Mosquera, 2012), we emphasis some ideas about teachers and their education.In these text, we have already highlighted Mosquera and Stobäus (1984) ideas, reaffirming that a good teacher, especially in the area of Physical Education, must have skills as manager, mediator and facilitator.

\section{Teachers Roles and Tasks}

Several features about a better teacher are highlighted on this professional can and should present aspects of behavior for effective and efficient teaching. Several authors, including Rios (2001) and Perrenoud (2000), stand about skills required for good teaching. We do not want somehow quantify or to list these conditions, but mainly reflect and point out on important demands in the teaching sphere.

Already we pointed out that Mosquera \& Stobäus (1984), based on studies of Worell and Stilwell, in the 80s, highlighted some guideline aspects of teaching that seem still 
well today, highlighting the roles of manager, mediator and facilitator. On these scores, then we will make a descriptive approach, also using other authors in addition, as well as our own reflection.

The teacher as manager should organize, plan, direct, implement and evaluate. In that sense, its role would be related to knowledge would have learning, human development and education. It should also meet the research conducted in the area of learning and development because these experiences provide subsidies for a better structuring and academic development.

Another aspect highlights how important this dimension is related to a deep self-management (ability that one has to put up herself and the other to solve their own problems). We believe that in today's society there is the importance of proficiency in work themselves, (re)build up, (re)invent to itself taking a reflective stance as a transforming agent of society and the environment in which it appears and acts.

Another aspect that highlight is linked to the ability to question constantly and learn to delegate responsibilities. Carefully plan their action to obtain accurate and comprehensive income is related to the ability to SBER manage the development process of learning of their students and manage them, which, as Perrenoud (2000), is linked to the knowledge of the contents to be taught, adjusting them to the level and possibilities of development of their students.

Any action of the physical education teacher will be directly regulated by the management of their own continuing education. No professional will be able to keep up with new demands if it is not in tune with their ongoing formation. Continually there is a need to update their cognitive resources, adapted to new work situations, the social environment changes and learning evolving.

Its performance in their training is a skill emphasized by Perrenoud (2000) as a basis for self-training. The author emphasizes that form is not only fulfilling bureaucratic obligations of participation in courses; it is to learn, is to change from various personal and collective procedures. Among these procedures, there is, for example: reading, experimentation, innovation, teamwork, participation in an institution project, regular personal reflection, among others. This line of action, Schon (cited by Perrenoud, 2000) makes it clear that the fundamental mechanism is reflective practice, in which the subject reflects to act and later establishes a reflection on the action taken.

Tardif (2000) points out that the professional knowledge are evolutionary and progressive and require a continued and ongoing formation and suggests that professionals should self-formed, be recycled through different means, after their university studies.

The teacher as a mediator must establish dyadic, warm and deep relations in a dyad with their schooling, setting a personal style. According Worell and Stillwell (cited by Mosquera \& Stobäus, 1984), this is related to aspects of humanistic exchanges in relation to their own students. As a mediator of human relations should be an expert in knowledge of how people interact and communicate. Its main goal should be the ability to maximize the quality of social and interactive environment.

We see that one of its functions, in this sense, would be to encourage pro-social be- 
havior, in helping people to be more cooperative with each other to share ideas and resources, to learn to listen to others, namely accept conflicting opinions, to assume their responsibilities and solve interpersonal problems productively, to play its role to effectively lead group.

It is professor of job seek to involve their students in teaching and learning processes and make their relevant teaching, being careful to allow space and time for new experiences, exchange of dialogue, search of knowledge and, above all, it is always open to meet and understand the interests of students, promoting more interesting and creative classes. Thus, it is the duty of the teacher, through its mediation, stimulates learning situations to be more useful and relevant, using innovative and differentiated strategies.

Meaningful learning from the perspective of Ausubel (2003), is understood as a process in which the new information to be assimilated stable and useful way, should interact with ideas (previously learned) relevant for this previously existing cognitive structure person, called subsumers, so that it can transform them into anchors, in a new set of knowledge. Now with new meaning, it is already widely known that the beneficial effects of any ongoing activity to preserve and improve health depend exactly on its adoption for a long period, known as lifestyle (pro)active.

This conception of learning to Moreira \& Masini (2006) was placed as opposed to rote learning, in which the new information would be stored in the mind in an arbitrary manner, i.e. with little or no connection with previous concepts.

The physical education teacher should be a facilitator, able to use specific skills to those students who require care and attention 'special', noting individual differences, acting so that their students adapt at different times of the own performance, constituting an opinion leader teacher and model of identity to younger people.

Thus, we consider it essential an act of close relationship with the family of the student and their school community in actions of various orders, especially those focused on health promotion in those environments. There are also social changes that have led to a significant increase in responsibilities to teachers and reinforce that teachers and the school will not be able to give an adequate response to these new demands while alone in this task. In this sense, there is a need to build a society that faces the education of new generations in a shared manner.

Based on this assumption, we think that the issue of health should be developed across the school, including all areas of knowledge, and in this context, we reinforce again the presence of the teacher of Physical Education, which has an enormous ability to motivate, to work with body and given his performance directly with specific activities of movement culture. Thus, it meets educational goals, with professional commitment, identified with the student, and has a key role in the involvement of his family in the process of Education for Health, encouraging and motivating for healthier and positive attitudes.

The facilitator's role is important in order to take account of individual differences and difficulties of each one, and try to adapt their ways, adjusting to the needs of their students. 
Another skill of the teacher as facilitator would be the possibility to integrate interdisciplinary teams and are more inclined to help student-problems, boosting their specific skills geared to special students.

These papers, analyzed separately here for convenience only, in practice crisscross up all the time, although dependent on the individual teaching style.

This is how we visualize a better teacher of Physical Education, inserted directly in Health Education at school.

We think he must have very important peculiarities, among them to have a role in human development, specifically by encouraging and care in the physical area, i.e. the culture of body movement, and because it is one of the largest Group facilitators in the case of his students, but also from fellow teachers in addition to the community. This leads us to believe that it is fundamental piece in a multidisciplinary team, which works from the perspective of an effective Education for Health.

Still must intervene and provide dynamic for the development of an active life. The literature has several arguments that emphasize the benefits of a physically active life and is paramount in the fight against diseases related to inactivity. In fact, we reinforce the idea that the student in the school environment, is in a very favorable phase to soak up the principles of active life that will base more practices for maintaining a healthy physical fitness, served to all other Life stages.

We suggest that it is extremely important to observe and be aware of the dynamic behavior and attitudes as a result of technological innovations and their implications with regard to health. As an example, would be to develop and propose ways of leisure and active recreation, as well as acting in the context of a preventive action of diseases for the benefit of health.

Knowing relate affectively, positive and healthy is highlighted by Mosquera \& Stobäus (1984), when they call our attention to the pedagogical studies of recent decades are facing with great force to better guide the education of teachers in an attempt to achieving greater meaning and depth in the interpersonal dynamics in educational environments, both teachers and their students. Promoting a more healthy and positive interpersonal relationship should be the basis of an approach that reconciles affectivity and well-being by developing self-image and self-esteem more realistic, very important factor in the help of the staff teaching own organization, so much so real as subjective as well as in understanding the environment they live in.

The authors point out that the approach to the crisis, transformations and changes that occur in adulthood, higher stage of human development, these are important and highlight the need for a constant and conscious restructuring.

\section{Physical Education Teachers Works}

The physical education teacher, when teaching activities of the body culture, you should use and integrate different sources of knowledge, indispensable condition for them to be listed in your context. Menestrina (1993) suggests a perspective toward the Health Education would make physical education, failing to act alone, if you went to a 
more combined operations with other curriculum subjects, due to broader purposes of the education system. This initiative would determine the progress of physical education as socio-educational and cultural activity, triggering the possibility more effective collaboration with a view to raising the standard of quality of life in society.

When we point these reflections for effective educational action toward Health Education, we recognize that it is exhausting, not only here, but also consider, as highlighted Mosquera \& Stobäus (1984), that teaching is not just the simple 'transmission of knowledge and its storage' in the mental structures of the student, but the possibility of transferring the knowledge acquired to effective practices into one's own life, lasting for many years later.

Thus, an effective pedagogy in terms of Physical Education, combined with a design of Health Education, should have the primary purpose of an education of human consciousness, to ensure health practices understood in general, as an individual attribute and with new values scope more toward Social Education.

The Physical Education teacher wants to "motivate" their students for the sport, and when you take it seriously, looking directly their students to practice in a way that will practice it also outside of the required classes. It is also necessary to consider that among the important goals of modern teaching of this subject, is the precept of Permanent Physical Education, that is, promoting and motivating the practice of sports for life.

In his Master Tesis, Baez (2008) had described the importance of the motivation of students in the university should be enhanced by the teacher, in education Physical classes even more in the training of physical education teacher, specially to one that will act in Basic Education and Medium Education.

Professor of Physical Education wants to "motivate" their students for the sport, and when taken seriously, works directly on their students to practice in a way that will practice it also outside the required classes. It is also necessary to consider that among the important goals of modern teaching of this subject, is the precept of Permanent Physical Education, that is, promoting and motivating the practice of sports for life.

Stobäus (1986) has emphasized the necessary training of teachers, but also the contextualization of its activities, in schools, some of them without even suitable places to these practices (minimum) better Physical Education School.

According to Costa (1989), interest in sports activity should not end within the end of term, with happens today with many teens. Instead, the sport should be a field of action and interesting and compelling experience for humans. To this, you can add that the sport should not be practiced by mere obligation but activity that develops pleasantly.

The role of the physical education teacher, when you want to motivate your students to sports standing practice, observe your goals, do everything possible to create positive stimuli values and appealing to the largest number of participants or even for all students.

Motivation in sport depends on the athlete's personality structure, especially how 
and to what extent become some relevant sporting needs in some feature of the structure of this individual. Intellectual development is a strong ally of the sportsman who seeks success; this vision gives any idea of the size of the need and usefulness of sports, linking the involvement of physical training with general issues, socializing functions, rewarding roles in sport.

Whereas the intellectual motivation enhancement in sport requires a certain intellectual level, it is understandable that this effort has a greater importance among researchers of Sport Psychology than actually among athletes or leaders.

De Marco \& Junqueira (1993) consider that it is worth remembering that motivation in sports is determined on the one hand, the specific possibilities of sport as action and experience of the field, and on the other hand, the influence of specific motivational aspects of personality. The latter far exceed the limits of the sport.

They keep saying motivations of athletes have been classified in various ways, ranging from basic physiological or psychological needs to the influence of factors arising from its vital development. Moreover, the reasons may be the result of the intrinsic nature of the task or of the award, both social and material.

\section{Conclusion}

One of the main objectives of Physical Education should be to get together and nurture feelings of accomplishment and satisfaction among students during the teaching processes that propose teachers and the learning of their students. That depends on different levels and different objectives, and indeed, we can see that every action presupposes an evolution that leads to a closure, which can generate new actions, like a growing spiral of development.

We believe that these joints of interdependent processes and meaning makers should effectively take into account the outstanding elements: motivation, positive psychology, and activities in physical education classes.

Considering the importance of this discipline, and be aware of its responsibility as teachers (and students) encourage discussions to implement the content and practice for their students to develop and expand for example their criticality are some of the responsibilities of the physical education teacher.

This requires that he not only "dumps content on their students", but refers them to a (self)growth, individually and together, with rattles ideas and achievements, working and putting them to experience "body new cultures". Every teacher needs a framework that assists in achieving the desired objective in relation to the human being who wants to help develop, the type of school and society we want to live and proposals you want your students can achieve over each of their lives.

The systematic articulation of a school community can promote well-being, and imply in a holistic-oriented vision, in direction to solve real and practical problems in the areas of Physical Education, Health and Education. That can result in a construction and expansion of their fields of knowledge of overcoming problems, and consequent possibility of reducing the uncertainty, providing theoretical and practical sup- 
port to motivate and can give elements to build a flowering of its partakers.

It regains that motivation and creativity are essential elements only and in physical education classes because they contribute substantially those more comprehensive and varied education of the students, assisting therefore in understanding the importance of citizenship, inclusion/full inclusion and other elements transverse to say schooling.

These, in turn, will enable later that those students are more upstanding and secure citizens, in their thoughts and actions, collaborating in the formation of a more just society.

Finally, we propose a careful rereading of aspects of the construction of the process of identity of the professional of Physical Education, and that it is structured as a transforming in their social context. It can be characterized as promoter of a new Pedagogy, focusing on the "how to be", "how to live", "how to know", providing effective means for the construction of a healthy man and a renewed social culture, and remembering subjects like Humanistic-existential Psychology, Positive Psychology and Health Education.

\section{References}

Ausubel, D. (2003). Aquisição e retenção de conhecimentos: Uma perspectiva Cognitiva. [Acquisition and Retention of Knowledge: A Cognitive Perspective]. São Paulo: Editora Plátano.

Baez, M. A. C. (2008). Relatos de discentes da Educação Física sobre sua formação. [Students Reports of Physical Education about Their Education]. Dissertação (Mestrado em Educação), Porto Alegre: Programa de Pós-Graduação em Educação da PUCRS.

Baez, M. A. C. (2015). O processo de construção do bem-estar e da qualidade de vida durante a formação em Educação Física e suas perspectivas de futuro à luz da Psicologia Positiva. [The Process of Building the Well-Being and Quality of Life during Training in Physical Education and Their Future Prospects in the Light of Positive Psychology]. Tese (Doutorado em Educação), Porto Alegre: Programa de Pós-Graduação em Educação da PUCRS.

Baez, M. A. C., Sampaio, A. A., Stobäus, C. D., \& Mosquera, J. J. M. (2012). Educação Física escolar e saúde: novos olhares frente a novos contextos. [School Physical Education and Health: New Looks forward to New Contexts]. EFDeportes.com, Revista Digital. Buenos Aires, año 17,173 , oct.

http://www.efdeportes.com/efd173/educacao-fisica-escolar-e-saude-novos-olhares.htm

Baez, M. A. C., Stobäus, C. D., \& Mosquera, J. J. M. (2013).Saúde, Psicologia Positiva, motivação e bem-estar na Educação Física Escolar. [Health, Positive Psychology, Motivation and WellBeing in Physical Education]. II Congresso Íbero-americano/III Congresso Luso-Brasileiro de Psicologia da Saúde, Atas. Faro-PT: UAlg. 1-17.

Baez, M. A. C., Stobäus, C. D., \& Mosquera, J. J. M. (2016). School Physical Education: Welfare, Motivation and Positive Psychology. In: International Conference on Positive Psychology and Cognitive Behavioral Therapy. Journal of Psychology \& Psychotherapy, Philadelphia, 36. http://cognitivebehavioraltherapy.conferenceseries.com/abstract/2016/school-physical-educati on-welfare-motivation-and-positive-psychology

Costa, L. P. (1989). Questões da Educação Física Permanente. [Issues of Permanent Physical Education]. Rio de Janeiro, RJ: EDUSRJ.

De Marco, A., \& Junqueira, F. C. (1993). Diferentes tipos de influências sobre a motivação de crianças numa iniciação esportiva. [Different Types of Influences on the Motivation of Child- 
ren in Sport Initiation]. In V. L. N. Piccolo (org.), Educação Física Escolar: Ser ou não ter? [Physical Education: To Be or Not to Have?] (pp. 95-101). Campinas, SP: Editora da UNICAMP.

Deci, E. L., \& Ryan, R. M. (1985). Intrinsic Motivation and Self Determination in Human Behavior. New York: Plenum Publishing Co. http://dx.doi.org/10.1007/978-1-4899-2271-7

Deci, E. L., \& Ryan, R. M. (2000). The "What" and "Why" of Goal Pursuits: Human Needs and the Self-Determination of Behavior. Psychological Inquiry, 11, 227-268. http://dx.doi.org/10.1207/S15327965PLI1104 01

dos Santos, B. S., Antunes, D. D., Mosquera, J. J. M., \& Stobäus, C. D. (2016). Teachers' Motivation Related to Teaching and Learning Processes. Creative Education, 7, 2011-2020. http://file.scirp.org/pdf/CE 2016090617185159.pdf http://dx.doi.org/10.4236/ce.2016.715202

Fita, E. C. (1999). O professor e a motivação dos alunos. [The Teacher and Student Motivation]. In J. A. Tapia \& E. C. Fita (Eds.), A motivação em sala de aula: O que é, como se faz. [The Motivation in the Classroom: What It Is, How It's Done] (4th ed., pp. 65-135). São Paulo: Loyola.

Gouvêa, F. (1997). A motivação e o esporte: Uma análise inicial. [Motivation and Sport: An Initial Analysis]. In M. A. Buriti (Ed.), Psicologia do Esporte (pp. 149-173). Campinas: Alínea.

Graziano, L. D. (2005). A felicidade revisitada: Um estudo sobre bem-estar subjetivo na visão da Psicologia Positiva. [Happiness Revisited: A Study of Subjective Well-Being in View of Positive Psychology]. Tese (Doutorado em Psicologia), São Paulo: Instituto de Psicologia da Universidade de São Paulo.

Huertas, J. A. (2001) Motivación: Querer aprender. [Motivation: Wanting to Learn]. Aiqué: Buenos Aires.

Machado, A. A. (1997). Psicologia do esporte: Temas emergentes [Sports Psychology: Emerging Issues]. Jundiaí, SP: Ápice.

Machado, A. A., \& Gouvêa, F. (1997). Importância da motivação para o movimento humano integração [Importance of Motivation for Human Movement Integration]. Integração, 4, 8590.

Magill, R. A. (1984). Aprendizagem Motora: Conceitos e aplicações [Motor Learning: Concepts and Applications]. São Paulo: Edgard Blücher.

Maslow, A. (1991). Motivación y Personalidad [Motivation and Personality]. Madrid: Ediciones Díaz de Santos.

Menestrina, E. (1993). A educação física numa concepção de educação para a saúde: Procedimentos didático-pedagógicos para uma ação eficaz [Physical Education in Designing Health Education: Didactic and Pedagogical Procedures for Effective Action]. Ijuí: Editora Unijuí.

Moreira, M. A., \& Masini, E. F. S. (2006). Aprendizagem significativa: A teoria de aprendizagem de David Ausubel [Meaningful Learning: Learning Theory of David Ausubel] (2nd ed.). São Paulo: Centauro Editora.

Mosquera, J. J. M., \& Stobäus, C. D. (1984). Educação para a saúde: Desafios para sociedade em mudança [Health Education: Challenges for Changing Society] (2nd ed.). Porto Alegre: D. C. Luzzato.

Mosquera, J. J. M., \& Stobäus, C. D. (2013). A Psicologia Positiva e suas implicações para a Saúde e a Educação [Positive Psychology and Its Implications for Health and Education]. In B. S. dos Santos, \& L. de Anna (Org.), Espaços psicopedagógicos em diferentes cenários [Psychopedagogic Spaces in Different Scenarios] (pp. 1-23). Porto Alegre: EdiPUCRS.

Paludo, S. S., \& Koller, S. H. (2007). Psicologia Positiva: Uma nova abordagem para antigas 
questões [Positive Psychology: A New Approach to Old Questions]. Paidéia, 17, 9-20.

http://www.scielo.br/pdf/paideia/v17n36/v17n36a02.pdf

http://dx.doi.org/10.1590/s0103-863x2007000100002

Perrenoud, P. (2000). Dez Novas Competências para Ensinar [Ten New Skills to Teach]. Porto Alegre: Artmed Editora.

Rios, T. A. (2001). Ética e competência [Ethics and Competence] (10th ed.). São Paulo: Cortez.

Seligman, M. E. (2004). Felicidade autêntica: Usando a nova psicologia positiva para a realização permanente [Authentic Happiness: Using the New Positive Psychology to Realize Your Potential for Lasting Fulfillment]. Rio de Janeiro, RJ: Objetiva.

Seligman, M. E. (2011). Florescer: Uma nova compreensão sobre a natureza da felicidade e do bem-estar [Flourish: A Visionary New Understanding of Happiness and Well-Being]. Rio de Janeiro: Objetiva. New York: Atria Books, 2012.

Stobäus, C. D. (1986). Problemas de Saúde Escolar [School Health Problems]. Veritas (Porto Alegre), 14, 37-46.

Tardif, L. (2000). Saberes profissionais dos professores e conhecimentos universitários: Elementos para uma epistemologia da prática profissional dos professores e suas consequências em relação à formação para o magistério [Professional Knowledge of Teachers and University Knowledge: Elements of an Epistemology of Professional Practice of Teachers and Their Consequences with Regard to Training for Teaching]. Revista Brasileira de Educação, 13, 1-24. http://educa.fcc.org.br/pdf/rbedu/n13/n13a02.pdf

\section{Submit or recommend next manuscript to SCIRP and we will provide best service for you:}

Accepting pre-submission inquiries through Email, Facebook, LinkedIn, Twitter, etc. A wide selection of journals (inclusive of 9 subjects, more than 200 journals)

Providing 24-hour high-quality service

User-friendly online submission system

Fair and swift peer-review system

Efficient typesetting and proofreading procedure

Display of the result of downloads and visits, as well as the number of cited articles

Maximum dissemination of your research work

Submit your manuscript at: http://papersubmission.scirp.org/

Or contact ce@scirp.org 